УДК 544.1: 615.451

ИССЛЕДОВАНИЕ КООРДИНАЦИИ ИММУНОАКТИВНЫХ ПЕПТИДОВ С ИОНАМИ МЕТАЛЛОВ КАК ОСНОВЫ ДЛЯ РАЗРАБОТКИ ИННОВАЦИОННЫХ ЛЕКАРСТВЕННЫХ ПРЕПАРАТОВ

\author{
Н.Д. Бунятян ${ }^{1}$, Г.М. Бобиев ${ }^{2}$ \\ ${ }^{1}$ ФГБУ «Научный центр экспертизы средств медицинского применения» Минздрава \\ России, г. Москва \\ ${ }^{2}$ Таджикский государственный педагогический университет им. С. Айни, г. Душанбе, \\ Таджикистан
}

Приведены результаты разработки иммуномодулирующего препарата тимоцин на основе координационных соединений дипептида изолейцил-триптофан с цинком, включающие синтез низкомолекулярных иммуноактивных пептидов методом активированных эфиров, определение иммуностимулирующей активности относительно тимозина $\alpha_{1}$, изучение координации дипептида изолейцил-триптофан с цинком, изучение иммуностимулирующей активности координационных соединений, результаты доклинических и клинических исследований тимоцина. Методом рН-метрического и оксредметрического титрования показано, что при взаимодействии цинка и дипептида изолейцил-триптофан в растворе образуются следующие комплексные формы: [ZnHL] $(\lg \mathfrak{x}=3,71), \mathrm{Zn}(\mathrm{HL})_{2}(\lg \beta=0,279), \mathrm{ZnL}(\mathrm{HL})(\lg \beta=6,6), \mathrm{Zn}_{2}(\mathrm{HL})_{2}(\lg \beta=188), \mathrm{Zn}(\mathrm{OH})(\mathrm{HL})$ $(\lg \beta=-0,256)$. Показано, что иммуностимулирующая активность координационных соединений в 2-8 раз превышает таковую исходного дипептида. Разработанный иммуномодулирующий препарат тимоцин показал высокую терапевтическую эффективность при лечении вирусных гепатитов, злокачественных новообразований различной локализации, псориаза и нейродермита. Тимоцин зарегистрирован в Таджикистане (рег. №ЛС №000085Т), Киргизии (КР №7137) и Туркмении (рег. №006371).

Ключевые слова: иммуномодулирующий препарат, тимоцин, координационные соединения, изолейцил-триптофан, цинк.

\title{
STUDY OF COORDINATION OF IMMUNOACTIVE PEPTIDES WITH METAL IONS AS A BASIS FOR THE DEVELOPMENT OF INNOVATIVE DRUGS
}

\section{N.D. Bunyatyan', G.M. Bobiev ${ }^{2}$}

${ }^{1}$ FGBI «Scientific Center for Expertise of Medical Products» Russian Ministry of Health

${ }^{2}$ Tajik State Pedagogical University named by S. Ayni, Dushanbe, Tajikistan

The results of development of the immunomodulator timotsin based on coordination compounds dipeptide isoleucyl-tryptophan with zinc, including the synthesis of low molecular weight peptides by immunoactive activated esters, determination regarding the immunostimulatory activity of thymosin $\alpha 1$, study of coordination of dipeptide isoleucyltryptophan with zinc, study the immunostimulatory activity of coordination compounds, the results of preclinical and clinical studies of timotsin. $\mathrm{pH}$-metric method and red-ox titration showed that the interaction of zinc and of dipeptide isoleucyl-tryptophan formed in solution following complex forms: [ZnHL] (lgæ = 3,71), $\mathrm{Zn}(\mathrm{HL})_{2}(\lg \beta=0,279), \mathrm{ZnL}(\mathrm{HL})(\lg \beta=6,6)$, $\mathrm{Zn}_{2}(\mathrm{HL})_{2}(\lg \beta=188), \mathrm{Zn}(\mathrm{OH})(\mathrm{HL})(\lg \beta=-0,256)$. It was shown that the immunostimulatory activity of coordination compounds is in 2-8 times greater than the starting dipeptide. 
The developed immunomodulatory drug timotsin showed high therapeutic efficacy in the treatment of viral hepatitis, malignant tumors of different localization, psoriasis and neurodermatitis. Timotsin is registered in Tajikistan (registration number of medical drug №000085T), Kyrgyzstan (medical drug №7137) and Turkmenistan (registration number 006371).

Key words: immunomodulatory drug timotsin, coordination compounds, isoleucyltryptophan, zinc.

В настоящее время уже не вызывает сомнений тот факт, что большинство заболеваний или возникает или сопровождается нарушениями деятельности иммунной системы. Для их коррекции используется большое количество иммуномодулирующих препаратов, полученных синтетическим путем. Поскольку они являются чужеродными для живого организма, при их применении часто возникают побочные явления. Альтернативой таким препаратам являются средства, созданные на основе эндогенных иммуноактивных пептидов. В 80-х годах XX века на основе тимусных экстрактов было разработано несколько препаратов - тималин, тактивин и другие, из которых в дальнейшем были выделены индивидуальные пептиды и изучены их биологические свойства. При этом установлено, что некоторые триптофансодержащие дипептиды обладают ярко выраженными иммуномодулирующими свойствами [12]. В число этих дипептидов входят изолейцил-триптофан и глутамил-триптофан. Препараты, созданные на основе таких пептидов, даже полученных синтетическим путем, не являются чужеродными организму, вследствие чего не обладают токсичностью и не оказывают побочного действия.

Поэтому особую актуальность приобретает разработка оптимальных методов химического синтеза низкомолекулярных иммуноактивных пептидов.

Также значительную роль в функционировании иммунной системы играет цинк [11].

Установлено, что при образовании комплексных соединений биологически активных соединений с ионами различных металлов увеличивается их специфическая активность [10], в том числе и пептидов [14]. Однако до настоящего времени на основе биокоординационных соединений иммунологически активных микроэлементов и низкомолекулярных пептидов не был разработан ни один лекарственный препарат. Вследствие этого изучение путей комплексообразования низкомолекулярных иммуноактивных пептидов с ионами биологически активных металлов, таких как цинк, и разработка на этой основе иммуномодулирующих препаратов широкого спектра действия, методов их стандартизации, технологических схем широкомасштабного производства являются актуальными, открывая новое направление в фармацевтической химии.

Целью данного сообщения является демонстрация эффективности применения такого подхода на примере разработки иммуномодулирующего препарата тимоцин.

Первым этапом исследований явился синтез низкомолекулярных иммуноактивных пептидов и выбор наиболее активного из них для разработки на его основе иммуномодулирующих препаратов. Для синтеза были выбраны фрагменты активного центра тимопентина и аналоги дипептида глутамил-триптофан.

Синтез в основном был проведен методом активированных эфиров путем ступенчатого наращивания пептидной цепи, начиная с С-конца. Для примера на рисунке 1 приведена схема синтеза гексапептидного аналога тимопентина.

Нами были синтезированы пептиды [4,9], некоторые из которых приведены в таблице 1. 
Исследование иммуностимулирующей активности показало, что наиболее активными были тимопентин и его гексапептидный аналог, дипептиды H-Glu-Trp-OH, HIle-Trp-OH, активность которых соответствовала активности тимозина $\alpha_{1}$ и бурсина $[1,2]$.

Для дальнейших исследований был выбран дипептид H-Ile-Trp-OH. Основанием для его выбора послужили отсутствие боковых функциональных групп аминокислот, что упрощает процесс его синтеза и его стимулирующее влияние на Т-хелперы и T-супрессоры, в отличие от тимогена, который оказывает стимулирующее влияние только на Т-хелперные клетки [12].

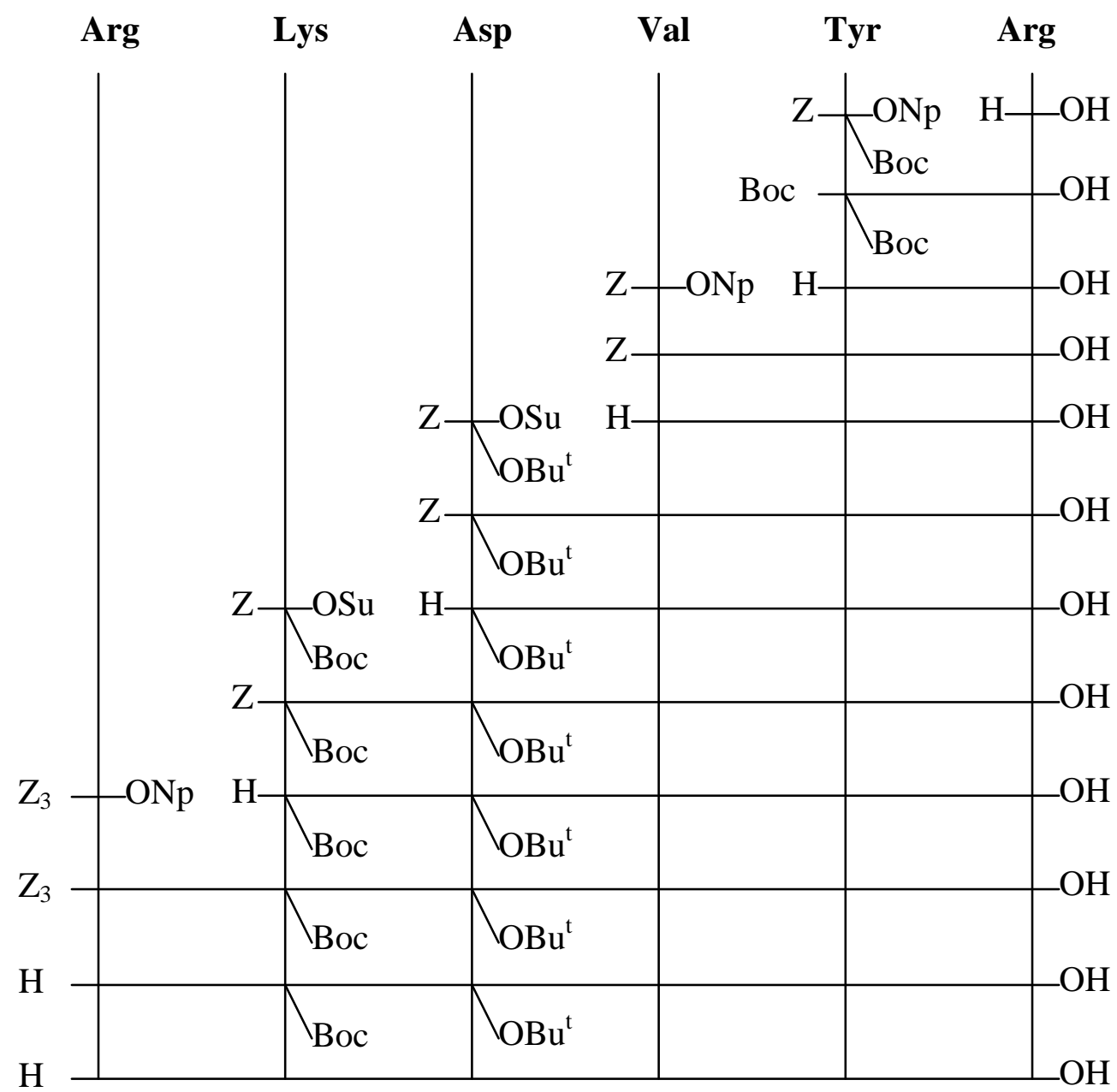

Рисунок 1 - Схема синтеза гексапептидного аналога тимопентина

Для производственных целей данный дипептид получали с использованием активированных (пентафторфениловых) эфиров, получаемых $\mathrm{c}$ помощью дипентафторфенилкарбоната, что позволило вводить активированные эфиры в реакцию конденсации без выделения из реакционной смеси и дополнительной очистки. Кроме того, применение при очистке защищенного дипептида колоночной хроматографии на силикагеле позволило исключить использование ВЭЖХ на стадии очистки свободного дипептида.

Структура и индивидуальность дипептида, полученного этим методом, были подтверждены данными аминокислотного анализа, ТСХ и ВЭЖХ, а также массспектроскопией. 
Таблица 1 - Синтезированные низкомолекулярные тимусные пептиды

\begin{tabular}{|l|l|}
\hline Вид пептида & Последовательность пептида \\
\hline Аналоги тимопентина & H-Arg-Lys-Asp-Val-Tyr-OH (тимопентин) \\
& H-Arg-Lys-Glu-Val-Tyr-OH \\
& H-Arg-Lys-Asp-Val-Trp-OH \\
& H-Arg-Lys-Asp-Val-Tyr-Arg-OH \\
& H-Arg-Lys-Glu-Val-Trp-OH \\
\hline Триптофансодержащие пептиды & H-Glu-Trp-OH (тимоген) \\
& H-Ile-Trp-OH \\
& H-Arg-Glu-Trp-OH \\
& H-Lys-Glu-Trp-OH \\
& H-His-Glu-Trp-OH \\
& H-Arg-Glu-Trp-NH \\
& H-Arg-Lys-Glu-Trp-OH \\
& H-Arg-Glu-Glu-Trp-Trp-OH \\
& H-Glu-Trp-Glu-Asp-Ala-OH \\
\hline Аналоги бурсина & H-Lys-His-Gly-NH 2 (бурсин) \\
& H-Lys-His-Gly-NH-NH-Trp-Glu-H \\
\hline
\end{tabular}

ВЭЖХ данного дипептида приведена на рисунке 2. Масс-спектр дипептида приведен на рисунке 3. Основной пик соответствовал массе иона $[\mathrm{M}+\mathrm{H}]^{+}$, которая составляла 318,95 .

На следующем этапе исследований был изучен процесс координации триптофансодержащих дипептидов с ионом цинка. Первоначально были определены константы кислотной диссоциации дипептида изолейцил-триптофан и построена его диаграмма распределения, которая приведена на рисунке 4. Как показала диаграмма распределения, при физиологических значениях $\mathrm{pH}$ в водном растворе дипептид изолейцил-триптофан присутствует во всех трех ионных формах - катионной, анионной и цвиттер-ионной.

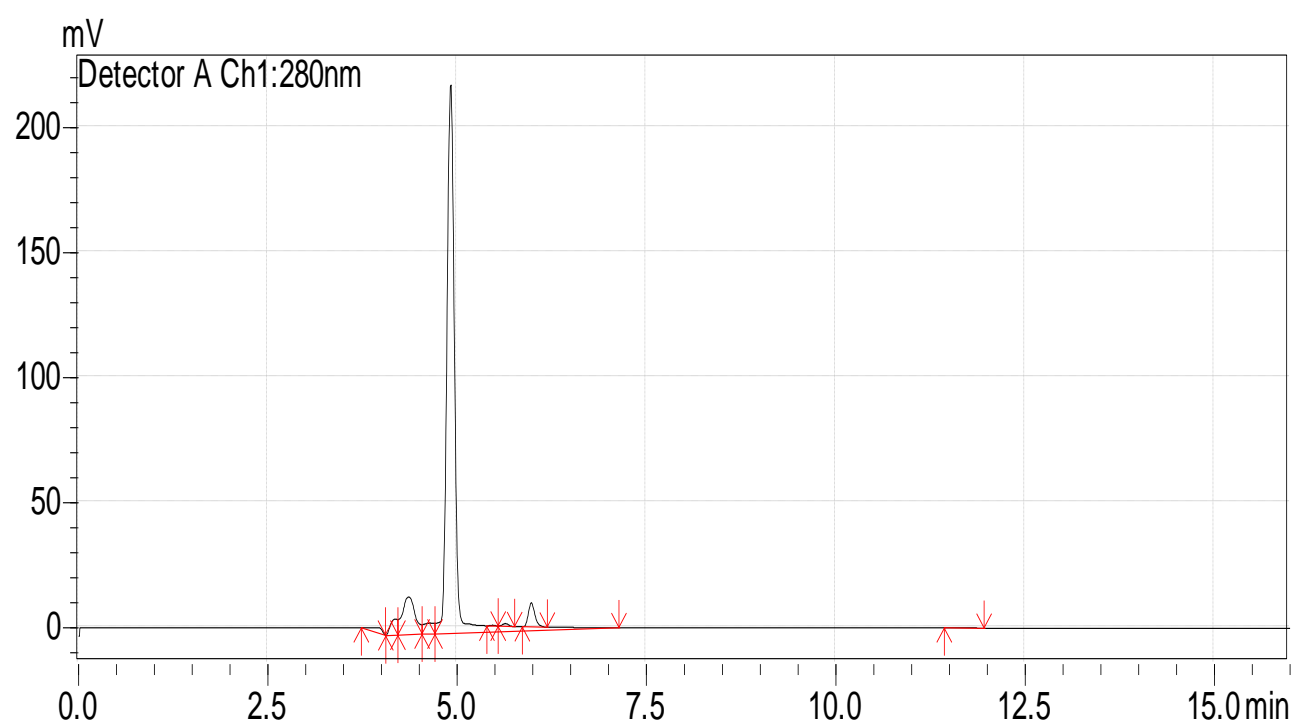

Рисунок 2 - ВЭЖХ дипептида изолейцил-триптофан (колонка Discovery C18 (25 см х 4,6 мм, размер частиц 5 мкм), подвижная фаза - смесь ацетонитрила и фосфатного буфера (40:60), скорость потока - 1 мл/мин, детектирование - при 254 и 280 нм, время элюирования - 30 минут 


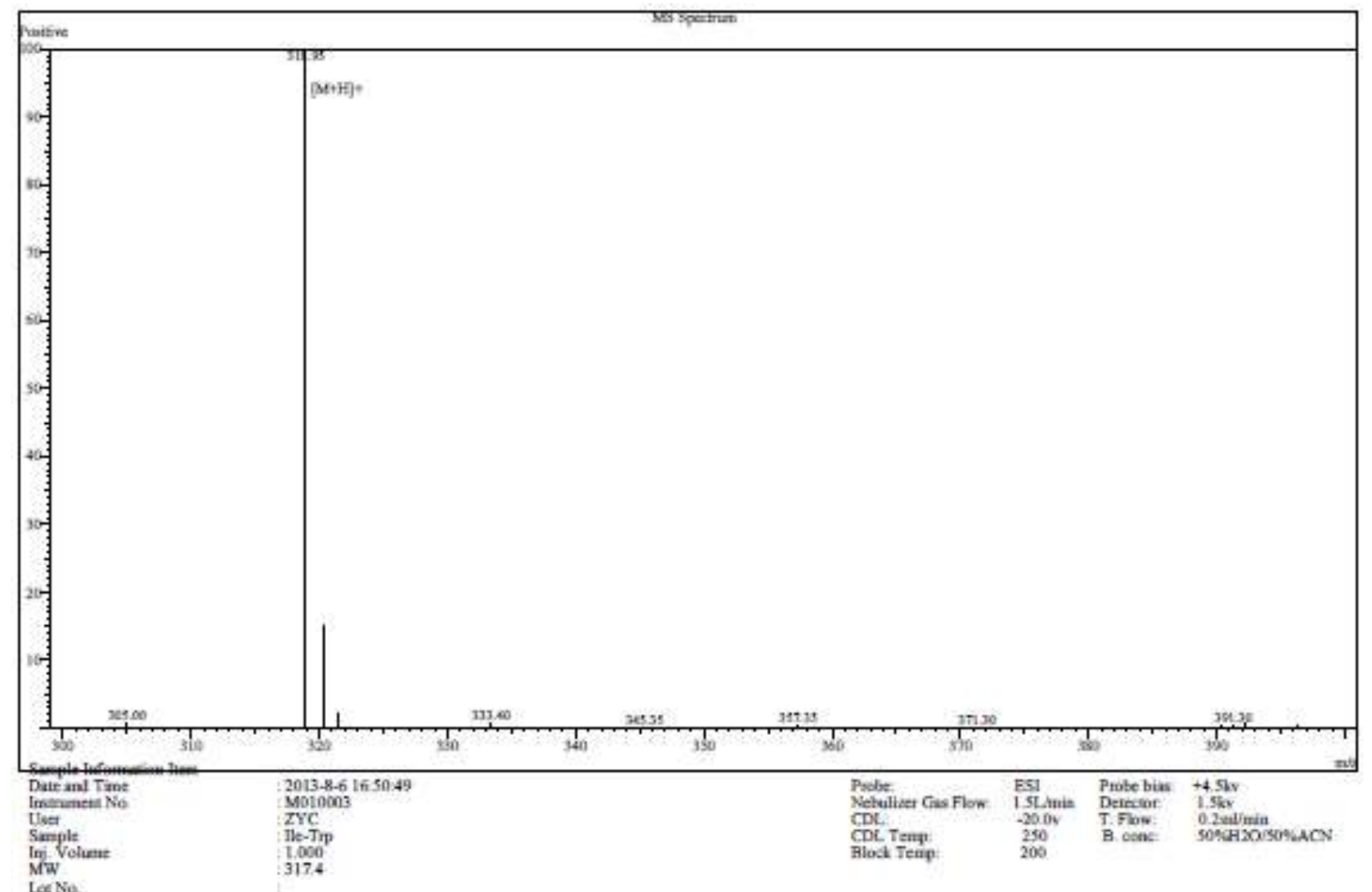

Рисунок 3 - Масс-спектр дипептида изолейцил-триптофан

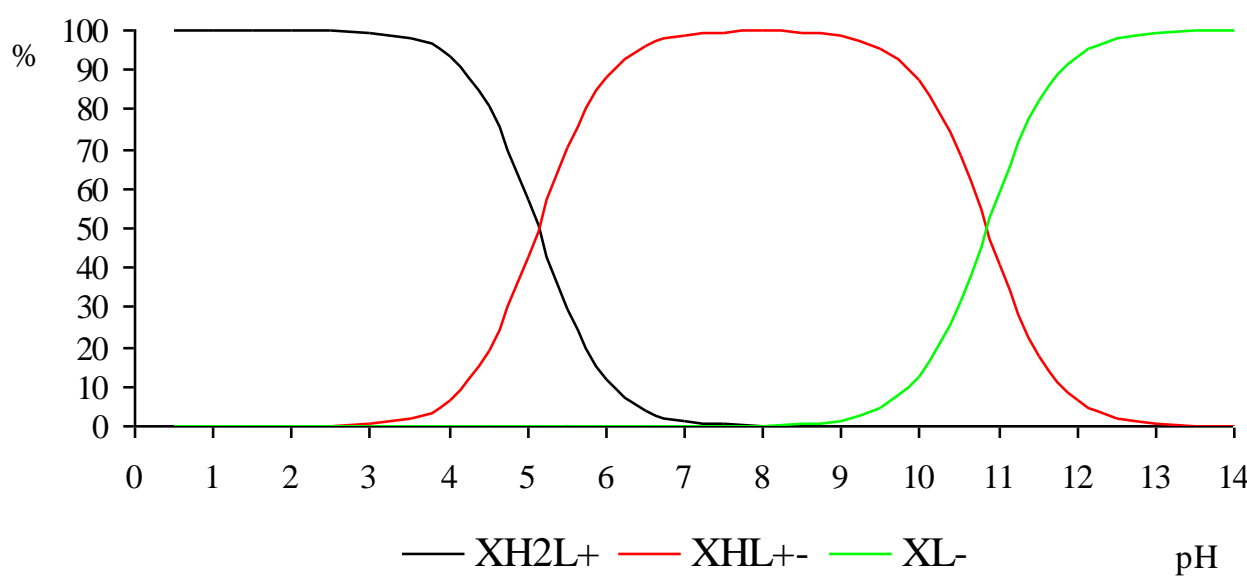

Рисунок 4 - Диаграмма распределения дипептида изолейцил-триптофан

Известно [8], что оптимальным способом получения координационных соединений аминокислот и пептидов в растворе является смешивание водных растворов и выдерживание их при температуре $60-70^{\circ} \mathrm{C}$ в течение 30 минут. Поэтому получение координационных соединений осуществляли непосредственным взаимодействием дипептида и ацетата цинка в водных растворах с выдерживанием при $60^{\circ} \mathrm{C}$ в течение 30 минут.

Затем проводили рН-метрическое титрование образующихся координационных соединений. Кривые титрования координационных соединений дипептида изолейцилтриптофан с ионом цинка приведены на рисунке 5. 
Как видно из рисунка 5, кривые титрования дипептидов и их координационных соединений отличаются друг от друга, что свидетельствует об образовании координационных соединений.

Расположение кривой титрования координационных соединений ниже кривой титрования дипептида свидетельствует об образовании в растворе комплексных форм, содержащих протонированные формы лиганда [13].

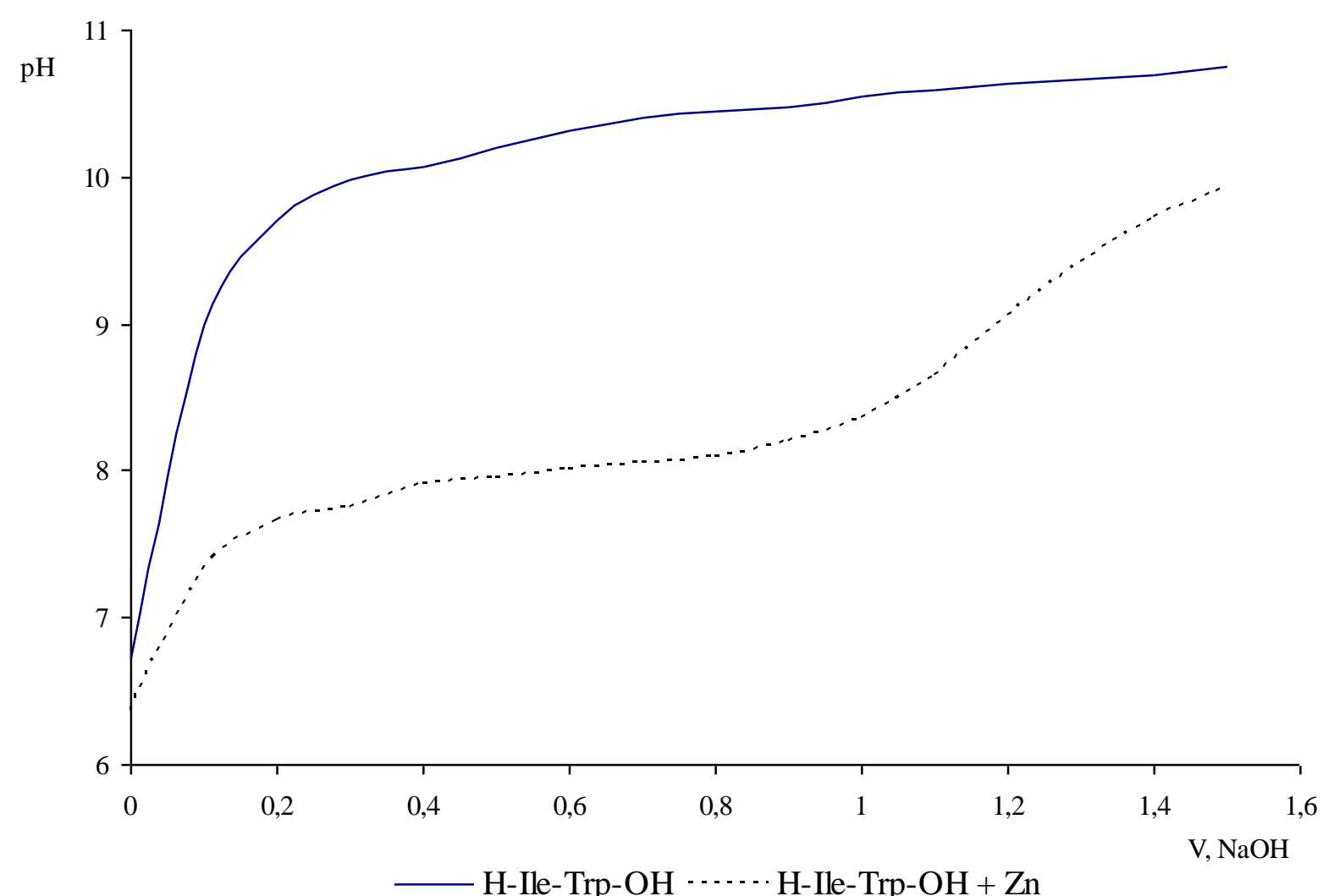

Рисунок 5 - Кривые титрования дипептида H-Ile-Trp-OH и его координационных соединений с цинком

Поэтому в данном случае необходимо учитывать протекание как ступенчатого комплексообразования,

$$
\begin{aligned}
& \mathrm{Zn}^{2+}+\mathrm{L}^{-} \leftrightarrow \mathrm{ZnL}^{+} \\
& \mathrm{ZnL}^{+}+\mathrm{L}^{-} \leftrightarrow \mathrm{ZnL}_{2}^{0}
\end{aligned}
$$

так и образование координационных соединений с протонированным лигандом и образование гидроксокомплексов:

$$
\begin{gathered}
\mathrm{Zn}^{2+}+\mathrm{HL}^{ \pm} \leftrightarrow \mathrm{Zn}(\mathrm{HL})^{2+} \\
\mathrm{Zn}(\mathrm{HL})^{2+}+\mathrm{HL}^{ \pm} \leftrightarrow \mathrm{Zn}(\mathrm{HL})_{2}{ }^{2+} \\
\mathrm{Zn}^{2+}+\mathrm{L}^{-}+\mathrm{H}_{2} \mathrm{O} \leftrightarrow \mathrm{ZnL}(\mathrm{OH})^{0}+\mathrm{H}^{+} \\
\mathrm{Zn}^{2+}+\mathrm{HL}^{ \pm}+\mathrm{H}_{2} \mathrm{O} \leftrightarrow \mathrm{Zn}(\mathrm{HL})(\mathrm{OH})^{+}+\mathrm{H}^{+}
\end{gathered}
$$

Значения констант образования комплексных форм, полученые с использованием метода окислительной функции, приведены в таблице 2 [6].

Численные значения констант образования координационных соединений позволяют рассчитать диаграммы распределения свободных и связанных в комплексе ионов металла, которые приведены на рисунке 6 . 
Таблица 2 - Константы образования комплексных форм цинка и дипептида изолейцилтриптофан

\begin{tabular}{|l|l|l|}
\hline Комплексная форма & $\begin{array}{l}\text { Обозначение } \\
\text { константы } \\
\text { образования }\end{array}$ & $\begin{array}{l}\text { Значение 1g константы } \\
\text { образования }\end{array}$ \\
\hline$[\mathrm{ZnHL}]$ & $\mathfrak{x}_{10110}$ & 3,71 \\
\hline $\mathrm{Zn}(\mathrm{HL})_{2}$ & $\beta_{10220}$ & 0,279 \\
\hline $\mathrm{ZnL}(\mathrm{HL})$ & $\beta_{10120}$ & 6,6 \\
\hline $\mathrm{Zn}(\mathrm{HL})_{2}$ & $\beta_{20220}$ & 188 \\
\hline $\mathrm{Zn}(\mathrm{OH})(\mathrm{HL})$ & $\beta_{1011}$ & $-0,256$ \\
\hline
\end{tabular}

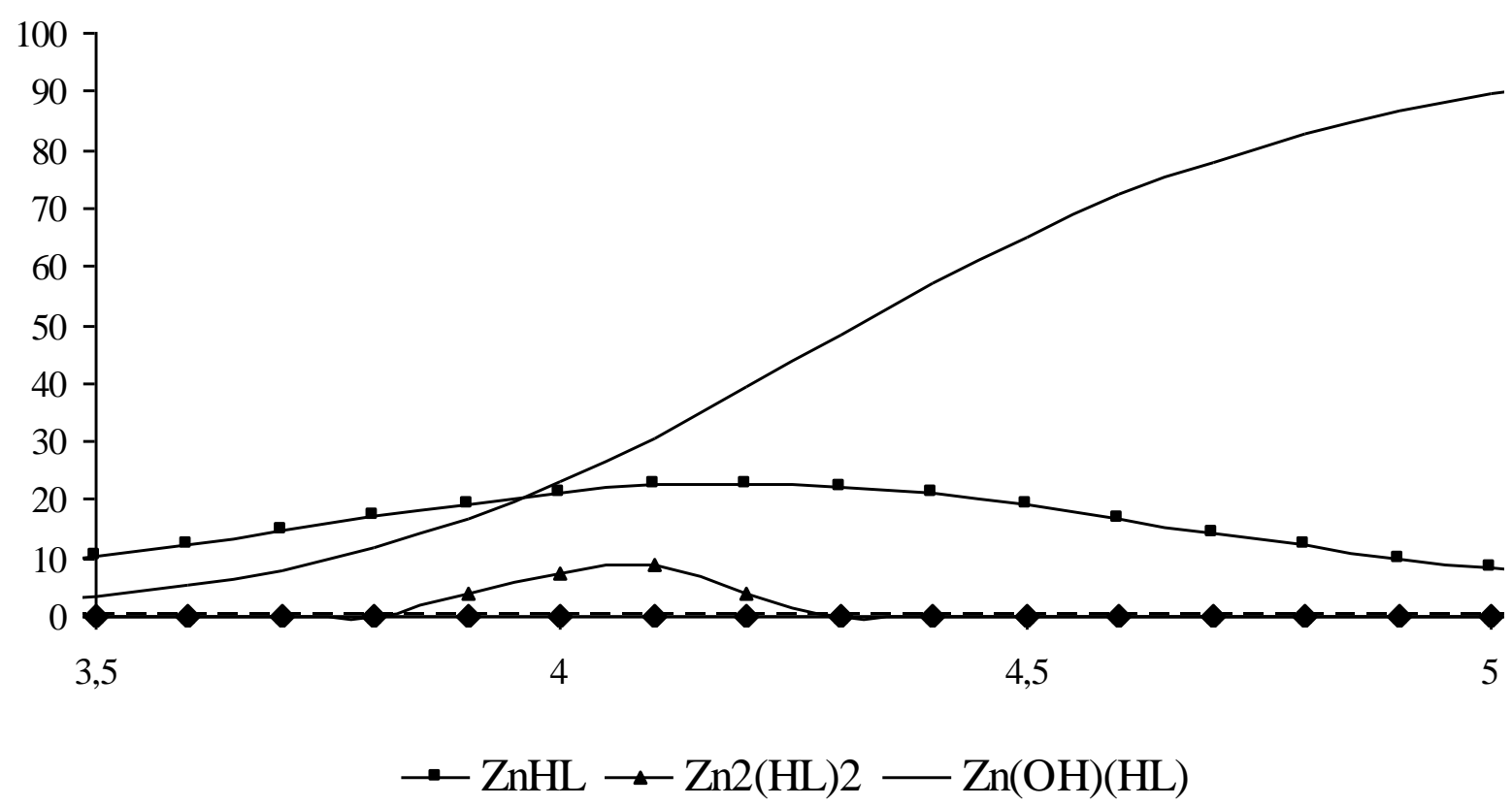

Рисунок 6 - Диаграмма распределения комплексных форм

Таким образом, при взаимодействии цинка и дипептида изолейцил-триптофан в водном растворе происходит образование координационных соединений с преимущественным образованием комплексных форм $\left[\mathrm{ZnHL}^{ \pm}\right]^{2+}, \quad\left[\mathrm{Zn}_{2}\left(\mathrm{HL}^{ \pm}\right)_{2}\right]^{2+}$, $\left[\mathrm{Zn}(\mathrm{OH})\left(\mathrm{HL}^{ \pm}\right)\right]^{2+}$.

Иммунологическую активность полученных координационных соединений изучали in vivo по увеличению титра антител у животных, иммунизированных противотейлериозной вакциной (табл. 3).

Полученные результаты показывают, что после координации с ионами металлов происходит увеличение иммунологической активности по сравнению с исходным дипептидом [6].

На основе координационных соединений цинка с дипептидом изолейцилтриптофан был разработан новый иммуномодулирующий препарат тимоцин [5], представляющий собой водный раствор координационных соединений цинка и дипептида изолейцил-триптофан с концентрацией действующего вещества $0,0157 \%$. 
Таблица 3 - Иммунологическая активность Н-Ile-Trp-OH и его координационных соединений с ионом цинка.

\begin{tabular}{|l|l|l|l|}
\hline \multirow{2}{*}{ Соединение } & \multicolumn{2}{|l|}{$\begin{array}{l}\text { Титр противотейлерийных } \\
\text { антител }\end{array}$} & $\begin{array}{l}\text { Увеличение титра } \\
\text { антител, раз }\end{array}$ \\
\cline { 2 - 3 } & РДСК & ИФА & \\
\hline H-Ile-Trp-ОН & $1: 5-1: 40$ & $1: 100-1: 1600$ & 2 \\
\hline H-Ile-Trp-OH $+\mathrm{Zn}^{2+}$ & $1: 10-1: 40$ & $1: 400-1: 1600$ & $2-8$ \\
\hline Контроль & $1: 5-1: 20$ & $1: 50-1: 800$ & - \\
\hline
\end{tabular}

Изучение иммуностимулирующих свойств тимоцина показало, что он в 2-8 раз увеличивает количество специфических антител и факторы защиты организма при совместном применении с различными вакцинами. При проведении клинических испытаний эффективность тимоцина проявлялась при лечении различных по своей этиологии заболеваний, таких как хронические диффузные вирусные заболевания печени, злокачественные новообразования, рецидивирующие дерматозы, аллергические состояния. Терапевтические эффекты тимоцина приведены в таблице 4 [3].

Таблица 4 - Терапевтические эффекты тимоцина

\begin{tabular}{|c|c|}
\hline Применение тимоцина & Терапевтические эффекты \\
\hline При вакцинации & Иммуномодулирующее \\
\hline $\begin{array}{l}\text { При лечении } \\
\text { заболеваний }\end{array}$ & $\begin{array}{l}\text { Антивирусное } \\
\text { Антиоксидантное } \\
\text { Гепатопротекторное } \\
\text { Иммуномодулирующее } \\
\text { Иммуностимулирующее }\end{array}$ \\
\hline $\begin{array}{lr}\text { При лечении } & \text { злокачественных } \\
\text { новообразований } & \text { различной } \\
\text { локализации } & \end{array}$ & $\begin{array}{l}\text { Гемостабилизирующее } \\
\text { Гепатопротекторное } \\
\text { Иммуномодулирующее }\end{array}$ \\
\hline $\begin{array}{l}\text { При лечении } \\
\text { нейродермита }\end{array}$ & Иммуномодулирующее \\
\hline
\end{tabular}

Тимоцин при лечении вирусных гепатитов проявил себя как антиоксидант, гепатопротектор и иммуномодулятор, чем обеспечивается его противовирусное действие, что привело к значительному повышению эффективности соответствующего лечения. При монотерапии только тимоцином, без применения интерферонсодержащих препаратов, срок нормализации измененных показателей в 1,5 раза был меньше, чем при использовании комплексного лечения с применением других иммуномодуляторов и интерферонсодержащих препаратов. Тимоцин зарегистрирован в Таджикистане (рег. № ЛС №000085Т), Киргизии (КР № 7137) и Туркмении (рег. №006371).

Таким образом, разработанный иммуномодулирующий препарат тимоцин показал высокую терапевтическую эффективность при лечении вирусных гепатитов, злокачественных новообразований различной локализации, псориаза и нейродермита. 


\section{Библиографический список}

1. Бобиев Г.М. Пептиды, обладающие активностью тимозина $\alpha_{1} / /$ Диагностика, лечение и профилактика инфекционных, инвазионных и незаразных болезней сельскохозяйственных животных: материалы научной конференции - Душанбе, 1995.-С. 88-92.

2. Бобиев Г.М. Синтез низкомолекулярных иммуноактивных пептидов // Материалы науч.конф., посвящ. 50-летию Института химии им. В.И. Никитина АН Республики Таджикистан.- Душанбе, 1996.-С.21.

3. Бобиев Г.М. Результаты клинических испытаний нового иммуномодулирующего препарата тимоцин // Вакцинология-2008. Совершенствование иммунобиологических средств профилактики, диагностики и лечения инфекционных болезней: тезисы докл. Всерос. науч.-практ. конф. - М., 2008.- С.25.

4. Бобиев Г.М. Синтез низкомолекулярных иммуноактивных пептидов //Материалы науч.конф., посвящ. 50-летию Института химии им. В.И.Никитина АН Республики Таджикистан.-Душанбе, 1996.-С.21.

5. Бобиев Г.М. Способ получения иммуностимулирующего препарата тимоцин. // Патент Республики Таджикистан № ТЈ 282,приоритет 08.05.1998.

6. Бобиев Г.М., Исупов С.Д., Гиесов А.Ш. и др. Влияние ионов металлов на иммуностимулирующую активность дипептидов // Проблемы современной химической науки: материалы юбил. науч.-практ. конф., посвящ. 40-летию химического факультета и 65-летию д.Х.н.. профессора Якубова Х.М.. Душанбе,1999. С.26-27.

7. Бобиев Г.М., Холназаров Б.М., Бунятян Н.Д. и др. Изучение состава координационных соединений цинка и дипептида изолейцил-триптофан методом окислительного потенциала // Вестник педагогического университета. 2011. № 2 (38). C.29-36.

8. Гликина Ф.Б., Ключников Н.Г. Химия комплексных соединений. М.: Просвещение, 1972. $168 \mathrm{c.}$

9. Дейгин В.И., Коротков А.М., Помогайбо С.В. и др. Синтез и исследование биологической активности иммуноактивных пептидов // Тезисн. докл. VII Всесоюз.симп. по химии белков и пептидов: тезисы .докл. Таллин, 1987. С.173.

10. Крисс Е., Волченскова И.И., Бударин Л.И. Координационные соединения металлов с лекарствами - новые эффективные терапевтические агенты // Коорд. химия. 1990. Т. 16. Вып. 1. С. 11-21.

11. Кудрин А.В., Скальный А.В., Жаворонков А.А. и др. Иммунофармакология микроэлементов. М.: Издательство КМК, 2000. 537 с.

12. Морозов В.Г., Хавинсон В.Х., Малинин В.В. Пептидные тимомиметики. СПб.: Наука, 2000. 158 с.

13. Шаров С.В. Физико-химическое исследование комплексообразования металлов IIIA подгруппы с комплексонами смешанного типа: Автореф. дис. канд. хим. наук. Тверь, 2006. - 21с.

14. Mrabet B., Jouini M., Huet J.et al. Potentiometric, colorimetric and spectroscopic study of copper (II) complex of leucine - enkephalin and tripeptides, containing tyrosine // J. Clin. et phys - chim. Biol. 1992. V 89, №11-12. P. 2187-2205.

$$
* * *
$$

Бунятян Наталья Дмитриевна - доктор фармачевтических наук, профессор, заместитель генерального директора по научной работе ФГБУ «Научный иентр экспертизы средств медищинского применения» Минздрава России. Область научных 
интересов: проблема создания новых лекарственных препаратов с антиоксидантной направленностью действия. E-mail: ndbuп@таil.ru.

Бобиев Гуломкодир Муккамолович - кандидат химических наук, доктор биологических наук, доктор фармачевтических наук, профессор кафедры органической и биологической химии Таджикского государственного педагогического университета им. С.Айни (Республика Таджикистан, Душанбе). Область научных интересов: синтез пептидов, разработка лекарственных препаратов на основе низкомолекулярных иммуноактивных пептидов и их координационных соединений с биологически активными металлами. E-mail: bobievgm@rambler.ru. 